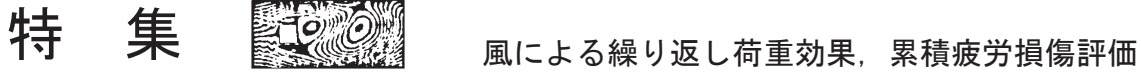

\section{橋梁の風疲労 \\ Fatigue on Bridges due to Wind Effects}

勝地 弘 ${ }^{*}$

Hiroshi KATSUCHI

1.はじめに

橋梁の疲労は，車両活荷重による変動応力が大きい ために, 継手形式, 構造ディテールの違いによって疲 労強度が著しく低くなり, 疲労耐久性が確保できなく なることで生じる。そのため, 道路橋示方書 ${ }^{1)}$ におい ては，疲労強度が著しく低くなる継手や溶接の品質確 保が難しい構造を避け, 活荷重によって生じる応力変 動の影響を評価して必要な疲労耐久性を確保すること を要求している。

一方, 風作用, 空力振動による疲労問題に関しては, 橋梁においては空力振動を制振することが基本である こと，またガス卜応答のように発現が避けられない場 合についても, ガスト応答の効果が風荷重に含まれて いること，さらにガス卜応答が大きくなる長大橋など の場合には, その振幅について検討することがあるが, 風の乱れもそれほど大きくなく,ほとんどの場合には, 活荷重たわみに比べて小さくなることから, 疲労応力 検討をするまでに至らないことがほとんどである。

ただし,アーチ系橋の細長い吊材, 支柱に対しては, 道路橋示方書に規定が定められている。この場合も， まずは風による有害な振動が発生しないような構造と することを規定している。その上で，より詳細には道 路橋耐風設計便覧 ${ }^{2}$ を参照しつつ, 振動が発生する風 速及び振動によって発生する応力を計算し, 必要な対 策を取ることとしている。また，制振対策としては，
曲げ剛性を大きくする，表面にロープを巻き付けたり 突起物を付ける，吊材をワイヤーなどで相互に連結す る等の耐風対策を示している。

ここでは，風による振動によって橋梁部材に生じた 被害事例, 道路橋示方書および道路橋耐風設計便覧に 示される風疲労の検討手法について紹介する。

\section{2，風による振動例}

道路橋示方書でも規定するようにアーチ系橋の吊材 やトラス橋の斜材，鉛直材においては，風による振動 がしばしば発現するとともに，部材端部に疲労き裂や 破断が生じることもある。以下に，橋梁に発現した空 力振動による風疲労の事例として, 四徳大橋（支間長 $150 \mathrm{~m}$ ，トラスドランガー橋 $)^{2)}$, 最上川橋 (支間長 $70.8 \mathrm{~m}$, トラス橋) ${ }^{3)}$, 生月大橋 (中央支間長 $400 \mathrm{~m}$, トラス橋) について紹介する ${ }^{4-7)}$ 。

四徳大橋（図 1）においては，完成数力月後に支間 中央付近の吊材が橋軸直角方向の $5 \sim 6 \mathrm{~m} / \mathrm{s}$ の風でトラ ス面内に振動するのが観測された。さらに，風速の上 昇とともに振動する吊材は端部側に移行し，風速 15〜 $17 \mathrm{~m} / \mathrm{s}$ では端部の吊材が振動しているのが認められた。 中央部の吊材（約 $22 \mathrm{~m}$ ）の最大振幅は $22.6 \mathrm{~mm}$ で，その 振動数は $3.45 \mathrm{~Hz}$ であった。共振時に計測されたガセッ トプレートの応力度は $207 \mathrm{MPa}$ であった。また，調 查の結果, 上下格点には 30 個以上のき裂が認められた。

* 1 横浜国立大学都市イノベーション研究院 教授

Professor, Department of Civil Engineering, Yokohama National University 
風速と吊材中央部の振動振幅との関係は図 2 に示寸通 りである。対策として，き裂部分を削り取って再度溶 接を行うとともに, 応力集中が少なくなるよう, 図 3 に示寸端部の補強を実施した。その結果, 最大応力度 は 30\%に低減した。さらに，吊材に直径 $32 \mathrm{~mm}$ のロー プ3本を 30 度の角度で巻き付けるトリップワイヤによ る対策を実施した結果, さらに振幅は減少することが 確認された。

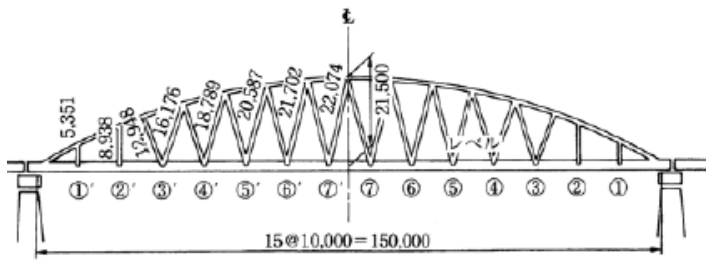

図 1 四徳大橋 ${ }^{2)}$

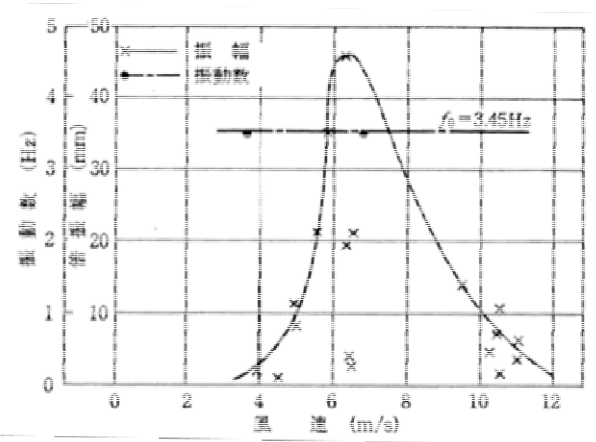

図 2 吊材の振動振幅と振動数 ${ }^{2)}$

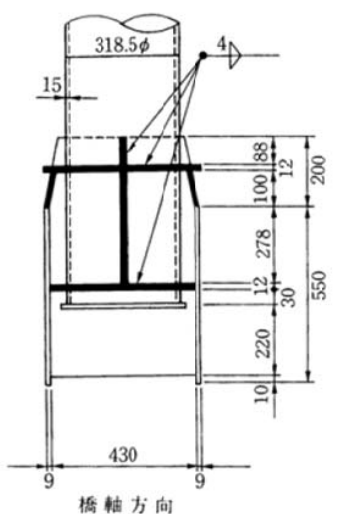

図 3 端部補強 ${ }^{2)}$

次に, 最上川橋（図 4）においては, 供用後 42 年が 経過した時点で $\mathrm{H}$ 型断面の引張斜材端部の複数個所に き裂が発見された。原因は定かではないが，架橋地点 が開けた地形であり冬季に乱れの小さな強風が作用す ること, 強風時に高次の空力振動が観測されたことか
ら，風による疲労き裂と推察される。対策として，図 5 に示すように，吊材端部に当て板補強が施されてい る。

また，1991 年に供用した生月大橋（図 6）において は, 供用 18 年後に中間橋脚付近の斜材端部にき裂が発 見された（図 7)。破面調查の結果等からこの損傷は, 風によって励起された振動によって発生したき裂が伝 播した後, 脆性破壊を生じたものと推定されている。 空力振動は, 約 $20 \mathrm{~m} / \mathrm{s}$ 超の風速域で発生した渦励振が, き裂の主原因であると報告されている。生月大橋の斜 材は, 部材長 $26.8 \mathrm{~m}$, 断面幅 $0.592 \mathrm{~m}$, 断面高 $0.5 \mathrm{~m}$ の 箱形断面であり, 細長比が大きい特徴がある。打撃試 験の結果, 斜材の主構面内 1 次モードの固有振動数, 減衰定数は，それぞれ $6.8 \mathrm{~Hz} ， 0.0017 \sim 0.018$ と報告さ れている。また, 発現した渦励振は主構面内 1 次モー ドが卓越しており, 風向は概ね橋軸直角方向であった。

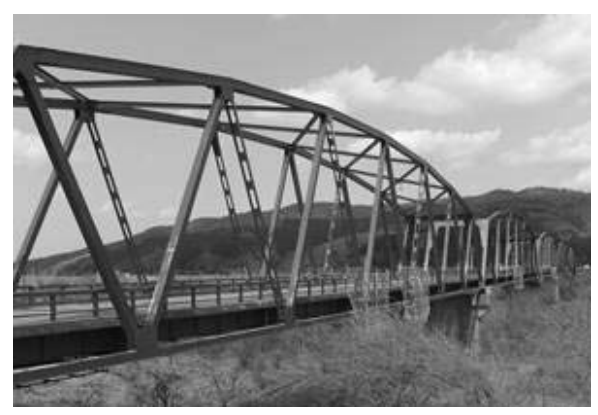

図 4 最上川橋
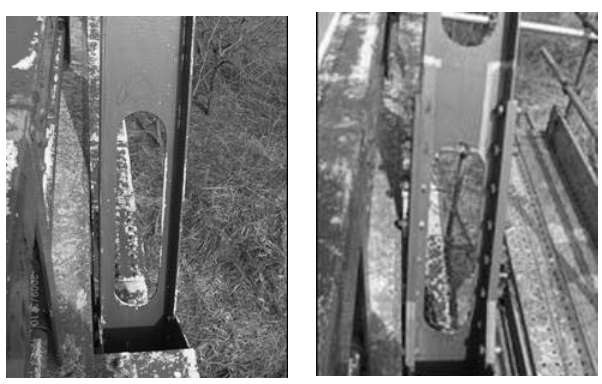

図 5 吊材端部の当て板補強（左は補強前）

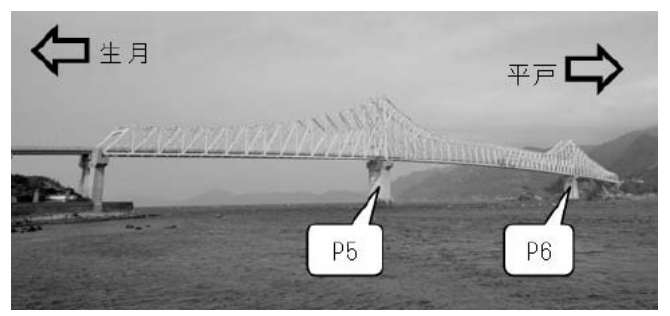

図 6 生月大橋 ${ }^{5}$ 


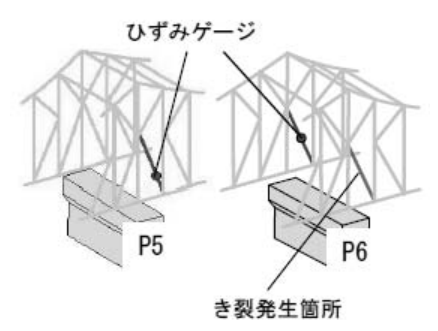

図 7 き裂発生個所 ${ }^{7}$

\section{3. 振動の予測と疲労検討}

橋梁部材に疲労を引き起こす空力振動としては, 渦 励振があげられるが，ここでは共振風速と振動時の部 材応力の算定方法について，道路橋耐風設計便覧にし たがって説明する。

1 ）共振風速

部材の渦励振が発現する風速（共振風速）は, 固有 振動数 $f_{s}$, 部材の代表長（気流直角方向の幅） $D$, 断面 のストローハル数 $S_{t}$ を定めることによって，式（1） によって推定することができる。

$$
U_{c r}=f_{s} \cdot D / S_{t}
$$

ストローハル数は，断面に固有の值であり，既往の 風洞実験結果をもとに, 表 1 のように与えられている。

\section{2 ）振動時の部材応力}

振動時の部材応力を正確に推定することは困難であ るが，渦励振による部材単位長さあたりの静的換算空 気力 $P_{l}$ を以下のように表す。

$$
P_{l}=\frac{1}{2} \rho B U_{c r}^{2} C_{L d y n}
$$

ここで， $\rho$ は空気密度， $U_{c r}$ は共振風速， $B$ は部材の代 表長， $C_{L d y n}$ は動的揚力係数である。

そして, $P_{l}$ が分かると部材曲げモーメント, 対応す る静的たわみが計算でき,これに振動時の共振倍率 $\pi / \delta$ (反は対数减衰率) を乗じることで最大振幅 $\eta$, 共振時 の応力のを求めることができる。

$$
\begin{gathered}
\text { (両端単純支持) } \quad \sigma=\frac{E \pi^{2} d}{2 l^{2}} \eta \\
\text { (両端固定) } \quad \sigma=2.65 \frac{E \pi^{2} d}{2 l^{2}} \eta
\end{gathered}
$$

ここで，最大振幅クは，

$$
\text { (両端単純支持) } \quad \eta=\frac{v^{2} d l^{4}}{0.4 \pi^{5} E I} C_{L d y n} \frac{\pi}{\delta}
$$

$$
\text { （両端固定） } \quad \eta=\frac{v^{2} d l^{4}}{2 \pi^{5} E I} C_{L d y n} \frac{\pi}{\delta}
$$

また，lは部材長，EIは部材の曲げ剛性である。

表 1 ストローハル数および動的揚力係数

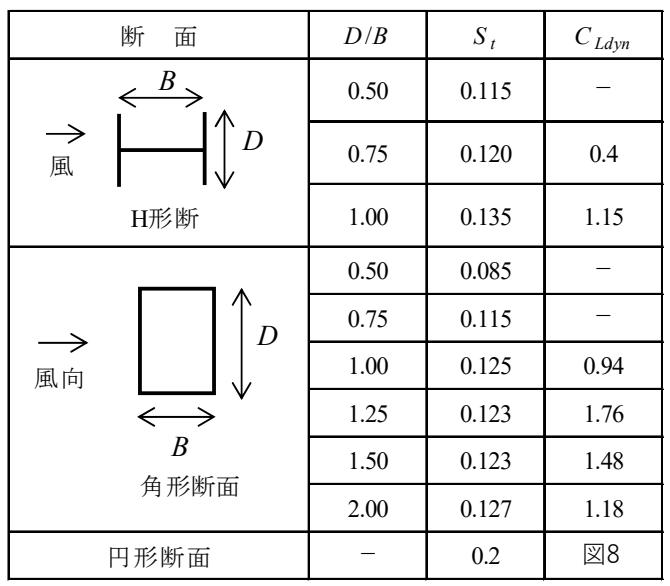

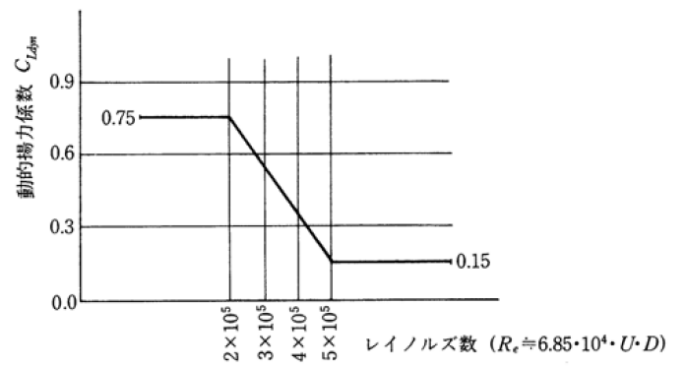

図 8 円断面の動的揚力係数

以上の関係をもとにすると，共振風速と部材の $l / d$ との関係は図 9 のようになる。また, 最大振幅, 最大 曲げ応力度の大きさは, 図 8 に示すように動的揚力係 数が臨界レイノルズ数 $\left(3 \times 10^{5}\right)$ 付近で急変するため に, $l / d$ の関数として滑らかな線を描くことはできない が，おおよそ表 2 に示すようになる。

したがって, 両端単純支持の場合, $l / d<40$ 程度であ れば，共振風速がかなり低く共振を起こしやすいが, 発生する曲げ応力度は小さく部材の疲労は問題になら ない。一方, 両端固定の場合, 共振風速が大きく剛性 が大きいことから振動による曲げ応力度が大きくなり， 振動が頻繁に生じる場合には疲労損傷が問題になると 考えられる。このため, 共振風速を $25 \mathrm{~m} / \mathrm{s}$ 程度まで高 めて一定の風速の風が吹き続ける頻度を少なくすると ともに, $l / d$ の最大值を 30 ないし 35 程度にするなどの 配慮が必要となる。 
一般にこの種の部材端部の接合には寸み肉溶接が用 いられるが，継手の疲労強度が低く，疲労に対する安 全性の確保に十分な注意が必要であり, 道路橋示方書 では，式(7)に示す外径の制限を設けている。

$$
d \geq \frac{l}{30} \sqrt{\frac{8}{t}} \text { ただし, } d \geq \frac{l}{40}
$$

ここで, $l:$ 部材長または有効座屈長 $(\mathrm{m}), d:$ 鋼管の 外径 $(\mathrm{m}), t:$ 鋼管の板厚 $(\mathrm{mm})$ 。

また，鋼管の厚さは共振風速とは無関係であるが， 最大振幅, 最大曲げ応力度とは反比例の関係にあるの で，厚さが $8 \mathrm{~mm}$ よりきいものは $l / d$ を 40 まで緩和で きることとしている。ただし，振動の発生を防止する か, 振動の性状を安全なものに変えるための特別の対 策を講じ，その効果を風洞実験等で十分に確認した場 合には，式(7)によらなくても良いとしている。

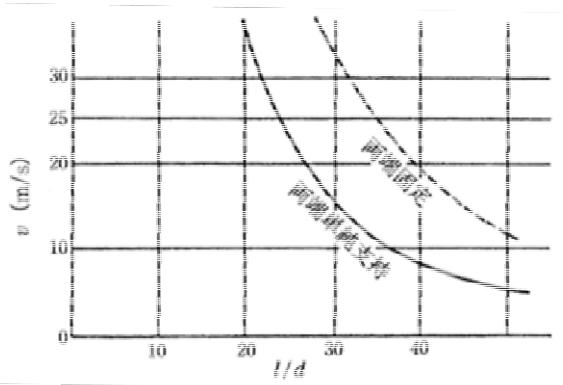

図 $9 l / d$ と共振風速の関係

表 2 最大振幅と最大曲げ応力度 $(l / d<40, t=8 \mathrm{~mm})$

\begin{tabular}{|l|c|c|}
\hline & 最大振幅 $\eta / l$ & 最大曲げ応力度 \\
\hline 両端単純支持 & $1 / 800 \sim 1 / 400$ & $40 \sim 60 \mathrm{MPa}$ \\
\hline 両端固定 & $1 / 800 \sim 1 / 400$ & $100 \sim 160 \mathrm{MPa}$ \\
\hline
\end{tabular}

\section{4. 制振対策}

橋梁の細長部材の制振対策として, 道路橋而風設計 便覧では以下のような方法を示している。

(1) 吊材の表面にらせん状にロープを巻き付けたり, 突起物を付けることで, 部材の後流に発生するカル マン渦列を乱し，励振力を抑える。

(2) 部材端部に有害な応力集中や二次応力が生じない ように疲労耐久性の高い構造とする。

(3) 部材の構造減衰を高め, 共振倍率を低下させる。 実際に前述の四徳大橋では端部補強により構造減衰 の増加が見られたが，一般に減衰の増加を推定する ことは困難である。また，部材相互をワイヤー等で 連結する方法があるが，これも減衰増加への寄与を 定量的に評価することは困難である。
(4) 部材の固有振動数を高め，共振風速を高める。た だし，十分に振動数を高めることは一般に困難であ り，逆に定着部の曲げ応力度も大きくなるので注意 が必要である。

\section{5。おわりに}

風による振動によって橋梁部材に生じた被害事例, 道路橋示方書, 道路橋而風設計便覧に示される振動の 予測と疲労検討法について紹介した。

既に述べたように, 橋杕や塔については, 空力振動 を発現させないことが基本となっており，また活荷重 の効果が大きいために, 風による疲労は一般的には問 題ない。また, 斜張橋ケーブルなど平行線ストランド ケーブルについては, 疲労強度の高い定着構造が採用 されており，これまでのところ問題は報告されていな い。一方で, 細長比の大きいアーチ系橋の吊材やトラ ス橋の斜材, 照明柱や標識柱などの橋梁付属物では, 本文で紹介したような検討, 照査が実施されるが，空 力振動は現地の風特性にも大きく影響を受けるために, 時に問題を生じることもあり, 注意が必要である。

参考文献

1)（社）日本道路協会, 「道路橋示方書 - 同解説, I 共通編・II 鋼橋編」，(2012.3)

2)（社）日本道路協会, 「道路橋而風設計便覧（平 成 19 年改訂版) 」, (2007.12)

3) 吉岡, 伊藤, 山口, 松本, 「鋼卜ラス橋の斜材振 動連成とモード減衰変化を利用した構造健全度 評価」, 土木学会論文集 A, Vol.66, No.3, pp.516-534, (2010.8)

4) 松田, 「低風速域で生じるトラス橋斜材の空力振 動」, 日本風工学会誌, 第 41 巻, 第 1 号, pp.10-15,

(2016.1)

5) 西川, 奥松, 中村, 岡林, 「空力励起振動する卜 ラス部材の遠隔計測の実現と長期運用」, 構造工 学論文集 Vol.61A，土木学会, pp.91-100, (2015.3)

6) 中村, 田中, 奥松, 西川, 橋本, 「実測データに 基づく生月大橋斜材の疲労損傷度の評価および 風況との相関分析」, 土木学会第 68 回年次学術講 演会講演概要集， I-315, pp.629-630，(2013.9)

7) 西川, 毛利, 奥松, 中村, 山口, 「鋼トラス橋の 部材振動を励起する風環境の観測・分析」, 土木 学会第 68 回年次学術講演会講演概要集, I-490,

pp.979-980, (2013.9) 